\title{
Rancangan Sirkulasi Pada Terminal Intermoda Bekasi Timur
}

\author{
Fahrani Widya Iswara dan Hari Purnomo \\ Departemen Arsitektur, Fakultas Teknik Sipil dan Perencanaan, Institut Teknologi Sepuluh Nopember (ITS) \\ e-mail: haripoeng19@gmail.com
}

\begin{abstract}
Abstrak-Arsitektur tidak terlepas dari program atau aktivitas seputar pergerakan dan perpindahan yang elemen-elemen mengisinya, baik manusia dengan berjalan kaki atau dengan menggunakan moda lain. Konfigurasi ruang dapat mempengaruhi bagaimana aktivitas dan pergerakan manusia didalamnya, konfigurasi spasial pada skala, luasan, dan batas dalam satu ruang dapat mengakibatkan efek 'mengarahkan' , membuat orientasi, sebagai pembeda program satu dengan lainnya, dan juga dapat mempengaruhi kecepatan gerak penghuninya. Rancangan sirkulasi dalam sebuah bangunan sangat dipengaruhi oleh siapa saja dan moda apa saja yang akan diwadahi dalam sebuah bangunan. Pada rancangan Terminal Intermoda Bekasi Timur, pengguna dan moda yang digunakan sangat beragam, sehingga membutuhkan kalkulasi dan pertimbangan tertentu dalam merancang untuk tercapainya ruang gerak yang nyaman dan berkelanjutan. Dengan menitikberatkan pada eksplorasi ruang sirkulasi, menghubungkan, menggabungkan, menumpuk dan memisahkan ruang-ruang berdasarkan analisa programatis, diharapkan rancangan mampu menjadi wadah arsitektural yang mampu menjawab kebutuhan penggunanya, serta mampu menjadi salah satu faktor penggerak untuk menopang aspek keberlajutan dari rancangan itu sendiri.
\end{abstract}

Kata Kunci-Ruang, Sirkulasi, Terminal.

\section{PENDAHULUAN}

$\mathrm{T}$ ERMINAL merupakan salah satu bangunan yang dalam proses merancangnya perlu memperhatikan aspek sirkulasi secara lebih seksama. Terdapat serangkaian permasalahan yang dapat timbul dalam sirkulasi sebuah bangunan yang melibatkan banyak orang, dan banyak jenis moda transportasi. Mengingat sirkulasi kaitannya dengan perpindahan dari satu titik ke titik lainnya, maka daalam rancangan Terminal Intermoda Bekasi Timur terdapat 3 area utama (titik) yang harus terhubung dengan konsep sirkulasi yang nyaman dan efektif.

Dalam arsitektur, sirkulasi adalah bagaimana manusia bergerak atau berpindah dan berinteraksi dengan bangunan (Britanica). Definisi lain menyebutkan, bahwa sirkulasi merupakan pergerakan melalui ruang, serta jalur pergerakan dapat dianggap sebagai elemen penyambung inderawi yang menghubungkan ruang-ruang satu bangunan. Secara singkat, sirkulasi dapat didefinisikan sebagai ruang antara ruang-ruang. Sirkulasi merupakan elemen esensial dalam arsitektur, karena itu sirkulasi merupakan hal yang cukup kompleks. Dalam merancang sebuah terminal Intermoda, perhitungan jumlah kapasitas manusia dan kendaraan menjadi hal yang perlu untuk dipertimbangkan.

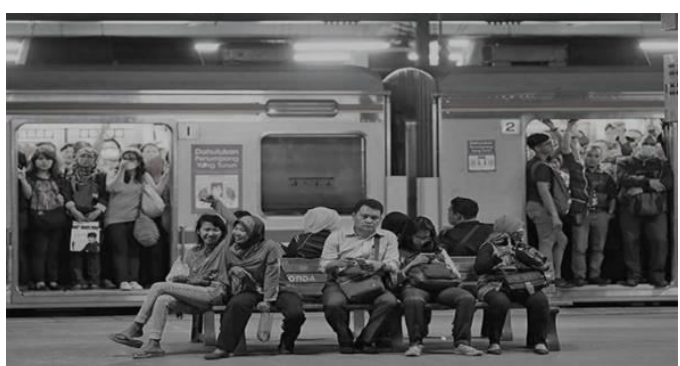

Gambar 1. Stasiun Kereta Api

Sumber: images. google

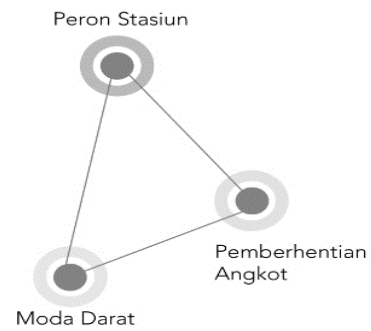

Gambar 2. Keterhubungan Program-Program Utama Sumber: Dokumen Pribadi

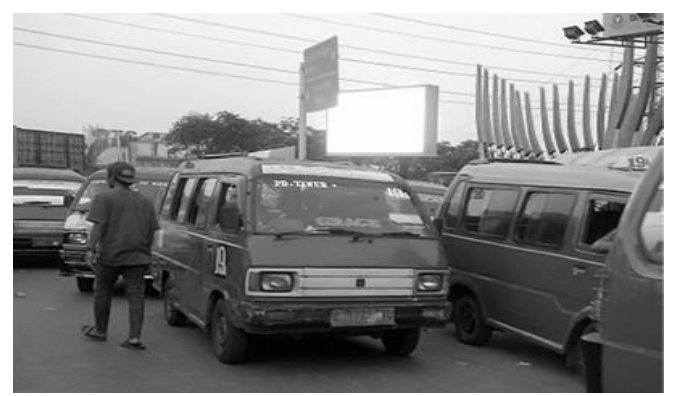

Gambar 3. Salah satu moda yang ada dalam Rancangan Terminal Sumber: Dokumentasi Pribadi

\section{PENGOLAHAN DATA DAN METODE RANCANG}

Dalam melakukan perancangan sebuah fasilitas umum yang berkaitan dengan berbagai macam moda transportasi, perlu adanya perhatian segi dimensi ruang, jumlah kapasitas manusia maupun transportasi yang harus diwadahi. Dalam rancangan Terminal Intermoda Bekasi Timur, ada 3 moda transportasi perhitungan kapasitas bangunan yang diperoleh dari kapasitas LRT dengan berdasarkan data LRT dan juga maupun beberapa asumsi sesuai dengan konteks. Data digunakan untuk menentukan kapasitas kendaraan umum (angkot) yang harus ditampung pada terminal, dan juga kapasitas parkir kendaraan. 


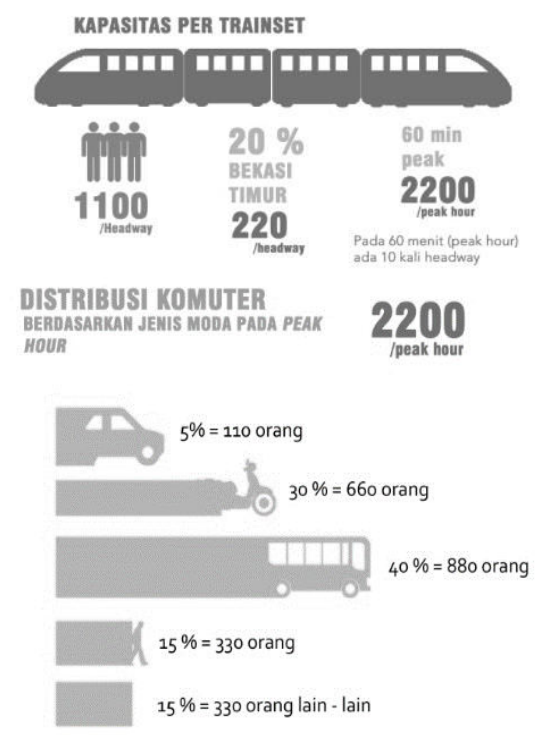

Gambar. 4. Perhitungan Kapasitas Pengguna. Sumber: Dokumentasi Pribadi

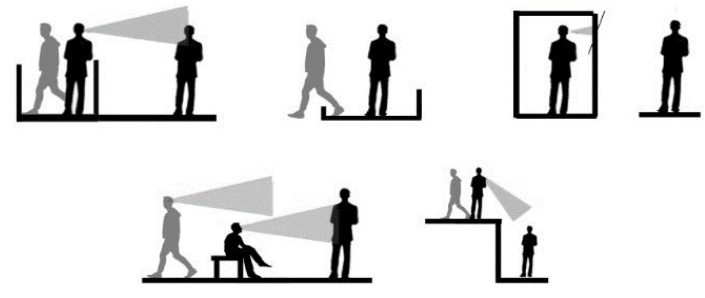

Gambar 5. Konektivitas Visual Pada Ruang. Sumber: Dokumentasi Pribadi

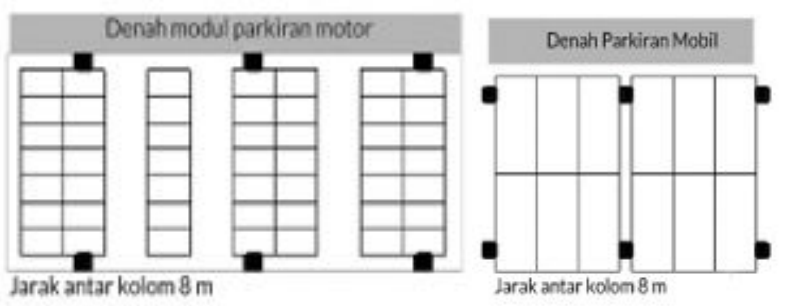

Gambar 6. Modul Parkiran

Sumber: Dokumentasi Pribadi

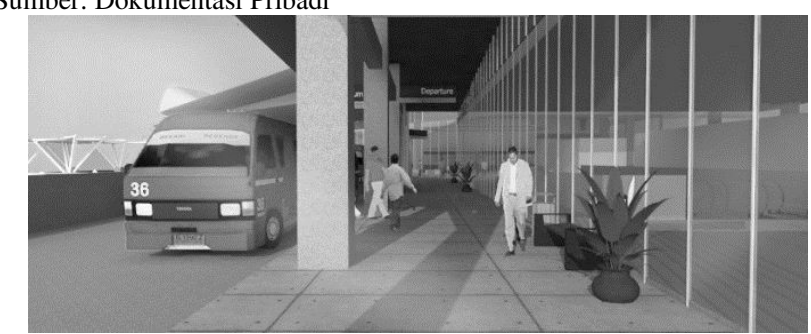

Gambar 7. Area Parkir Kendaraan

Sumber: Dokumentasi Pribadi

Pada dasarnya ada 3 tipe sistem sirkulasi, yang mempengaruhi pada tapak ruang dan struktur, tipe tersebut adalah tipe pejalan kaki, tipe roda dua tanpa motor dan sistem kendaraan bermotor, termasuk didalamnya mobil dan kereta [1]. Namun, dalam konteks rancangan Terminal Intermoda Bekasi Timur, sistem sirkulasi dibagi lagi berdasarkan jenis kendaraan, yaitu; pejalan kaki (penumpang, maupun non

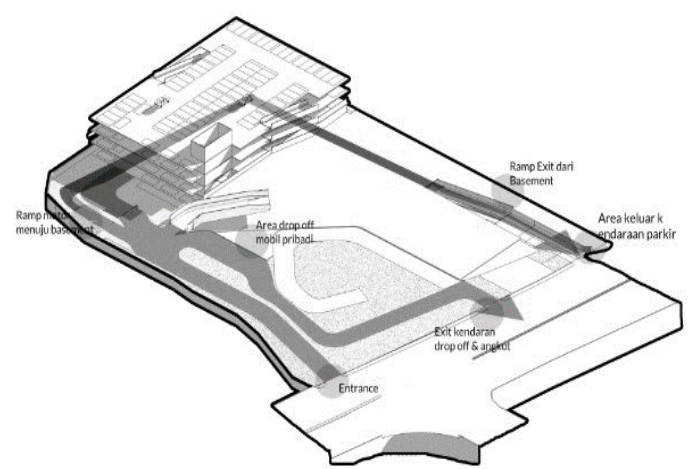

Gambar 8. Sirkulasi Kendaraan Pribadi Sumber: Dokumentasi Pribadi

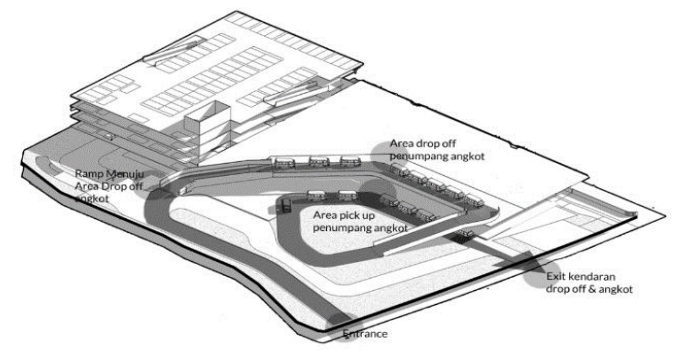

Gambar 9. Sirkulasi Kendaraan Umum Sumber: Dokumentasi Pribadi

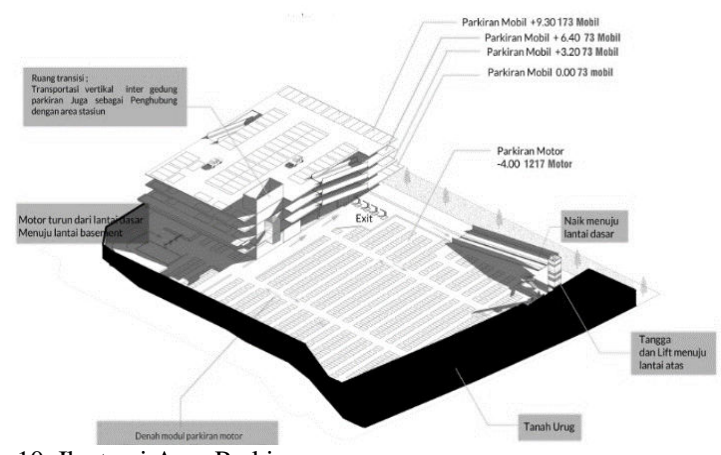

Gambar 10. Ilustrasi Area Parkir Sumber: Dokumentasi Pribadi

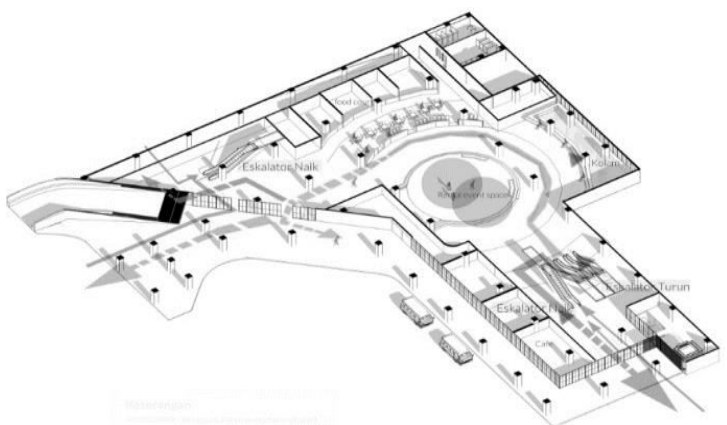

Gambar 11.Sirkulasi Pejalan Kaki Lantai Dasar Sumber: Dokumentasi Pribadi

penumpang), kendaraan roda dua (pribadi maupun umum), kendaraan roda empat (pribadi dan umum), dan kereta LRT. Semua sistem sirkulasi tersebut mempunyai karakteristik yang berbeda, dan juga meninjau sisi keamanan dan kenyamanan pengguna, maka sistem sirkulasi ini harus terpisah namun tetap terhubung satu dengan lainnya. 


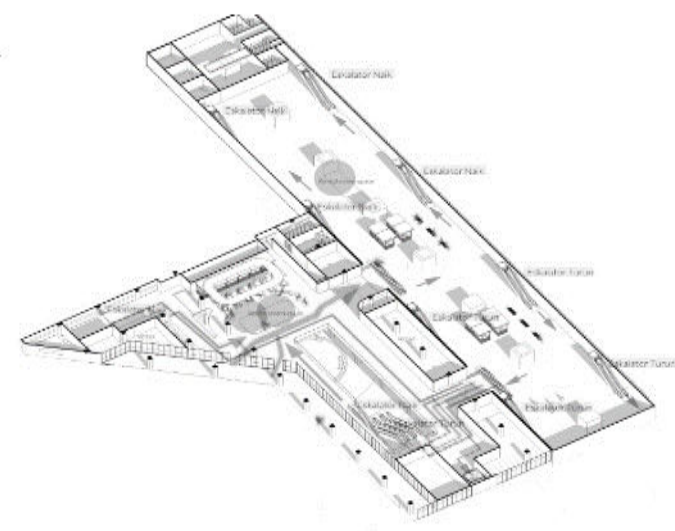

Gambar 12. Sirkulasi Pejalan Kaki Lantai 2

Sumber: Dokumentasi Pribadi

Berikut beberapa karakteristik sistem sirkulasi berdasarkan tipenya:

\section{1) Sistem Pejalan Kaki}

Sistem pejalan kaki memiliki ciri longgar (loose), fleksibel terhadap gerakan, kecepatan gerak rendah, skala manusia. Sistem ini merupakan sistem yang memberikan paling banyak keleluasaan kepada perancang, karena kemampuan manusia untuk berpindah, bertenti [1]. Perancang hendaknya mampu mengarahkan, pergerakan manusia menuju titik-titik yang diinginkan. Karena itu eksplorasi ruang sirkulasi menjadi bervariasi, ditambah dengan pertibangan akses visual dalam sirkulasi juga menjadi perhatian khusus dalam merancang ruang sirkulasi pejalan kaki. Dalam rancangan ini, pergerakan manusia juga memfokuskan terhadap apa yang dilihat oleh pengguna, kaitannya dengan fungsi keamanan dan juga komersial.

\section{2) Sistem Kendaraan}

Berbeda dengan sistem pejalan kaki, sistem kendara merupakan sistem yang memiliki persyaratan paling kompleks. Sistem ini mewadahi kendaraan dengan ukuran, kecepatan gerak dan manuver yang berbeda-beda dan terstandar. Sering kali rancangan sistem sirkulasi kendaraan menuntut hasil yang efektif dan efisien. Pada rancangan Terminal Intermoda Bekasi Timur, sistem kendaraan merupakan hal yang pertama kali dirancang untuk menentukan struktur dasar bangunan. Kolom yang ditempatkan dengan pola grid dengan jarak $8 \times 8$ meter dianggap menjadi pola yang paling efektif dalam merancang area sirkulasi kendaraan yaitu gedung parkir. (Gambar 5)

\section{HASIL DAN EKSPLORASI}

Susunan dari sistem sirkulasi harus fungsional, membawa orang-orang ke lokasi-lokasi yang dinginkan dengan cara yang aman, efisien dan menyenangkan. Selain itu, perlu dipahami bahwa didak ada satupun sistem sirkulasi yang terlepas dari setidaknya satu dari yang lainnya, akibatnya sistem-sistem yang berlainan bertemu, bersilangan, berjajar, bahkan berpencar terhadap satu dan lainnya. (Todd). Dalam rancangan Terminal Intermoda, eksplorasi penempatan sirkulasi yang saling bersilangan atau bersejajar dapat ditemukan dalam beberapa titik (Gambar 7), salah satunya untuk menciptakan kesan terpisah namun tetap terhubung.

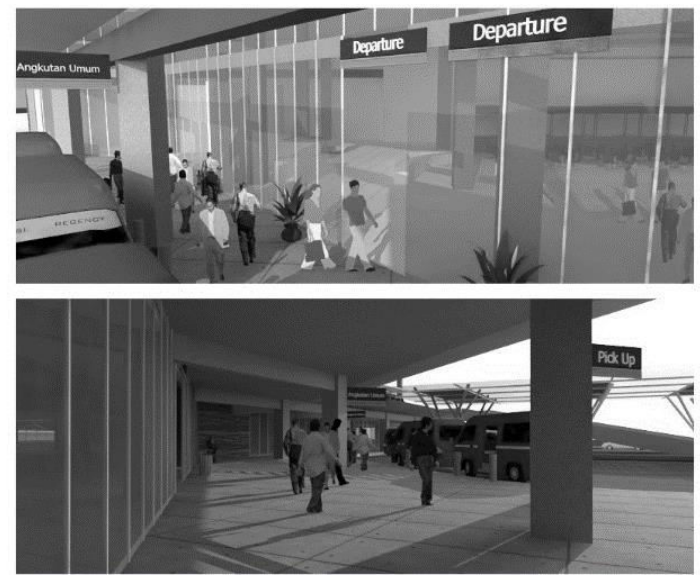

Gambar 13. Ilustrasi Pejalan kaki di area Keberangkatan dan kedatangan Sumber: Dokumentasi Pribadi

Seperti yang sudah disebutkan bahwa 'pemisahan' atau dengan kata lain pembedaan area sirkulasi menurut tipenya perlu dilakukan dalam rancangan Terminal Intermoda Bekasi Timur untuk fungsi keamanan dan kenyamanan. Berikut penjelasan lebih rinci mengenai setiap tipe sistem sirkulasi.

\section{A. Kendaraan}

Terdapat beberapa moda kendaraan yang difokuskan untuk diwadahi di rancangan ini, yaitu: kendaraan pribadi berupa motor dan mobil baik yang parkir maupun yang hanya dropoff, lalu kendaraan umum roda 4 berupa angkot yang menjadi program utama, selain itu taksi sebagai pendukung, dan kendaraan umum roda 2 berupa sepeda motor ojek. Keseluruhan sistem sirkulasi ini dirancang menjadi satu kesatuan yang diharapkan mampu mengakomodasi aktivitas gerak didalamnya secara efektif dan nyaman.

Masuk pada hasil eksplorasi, rancangan, Area sirkulasi kendaraan bermotor roda 2 dan 4 berada di setiap lantai. Terdiri dari area parkir, drop off, pickup, sirkulasi, dan Service. Sirkulasi kendaraan pribadi dan umum pada awalnya menjadi satu pada area entrance (Gambar 8). lalu terpisah pada sebuah persimpangan di dalam, untuk meminimalisir terjadinya penumpukan dan kesemerawutan. Untuk kendaraan pribadi masuk ke dalam area parkir dimana kendaraan roda 2 berada di lantai basement dan kendaraan roda 4 berada di lantai dasar sampai lantai 4. Sedangkan untuk kendaraan umum berupa angkot, diarahkan untuk naik ke area drop-off (keberangkatan) di lantai 2 untuk menurunkan penumpang lalu turun ke lantai dasar ke area pick up (kedatangan) untuk menaikkan penumpang (Gambar 9). Luasan dan jumlah kendaraan yang ditampung sudah melalui tahap perhitungan kebutuhan ruang rancangan Terminal Intermoda Bekasi Timur ini. Peletakkan Massa gedung parkir juga dipengaruhi oleh dampak kepadatan lalulintas disekitar lahan.

Pemisahan sistem sirkulasi juga tidak hanya dari jenis modanya saja namun dapat dipisahkan dari segi arah pergerakan dominan elemen yang mengisinya, seperti pemisahan area keberangkatan dan kedatangan dengan leveling ini untuk meminimalisir titik-titik pertemuan kendaraan dan manusia dan juga posisi pintu masuk dan keluar kendaraaan juga dipisahkan untuk meminimalisir potensi persilangan yang menimbulkan kemacetan. 


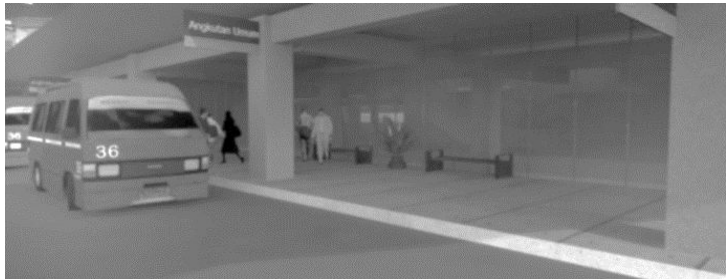

Gambar 14. Perspektif Bangunan.

Sumber: Dokumentasi Pribadi

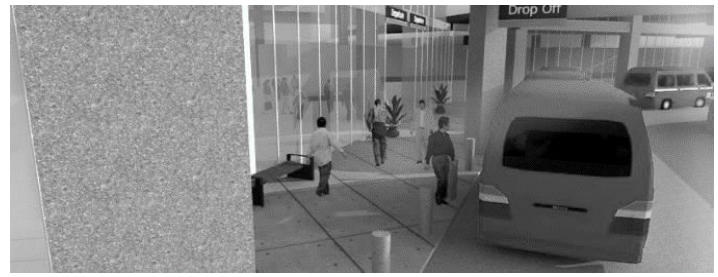

Gambar 15. Perspektif Bangunan

Sumber: Dokumentasi Pribadi

\section{B. Pejalan Kaki}

Perjalanan dalam suatu sistem sirkulasi memiliki maksud tertentu dan berorientasi ke tempat tujuan dari titik A ke titik B dan juga bersifat rekreasi (Todd). Kebanyaakan dari sistem sirkulasi harus mampu menampung kedua fungsi tersebut. Kesulitan yang kerap kali ditemukan adalah ketika para pelaku perjalanan yang bersiat rekreasi dan berorientasi ke suatu tempat tujuan menggunakan sistem yang sama. Perjalanan yang berorientasi pada tujuan tertentu cenderung bersifat langsung dan efisien, sedangkan dengan orientasi rekreasi cenderung berpindah dengan latar belakang view yang menarik dan dengan kecepatan yang rendah.

Dengan mengacu pada konteks desain dan lingkungannya, dalam rancangan Terminal Intermoda Bekasi Timur didominasi oleh pengguna yang melakukan kegiatan mobilitas yang berorientasi pada tujuan tertentu yaitu moda lain berupa stasiun LRT. Sehingga rancangan ruang sirkulasi area keberangkatan menuju stasiun dibuat langsung dan cepat agar sirkulasi lebih efektif. (Gambar x) Sedangkan pada area kedatangan, rancangan ruang sirkulasi mencoba untuk menggabungkan antara langsung dengan rekreatif, dengan mempertimbangkan pengguna yang didominasi oleh kalangan komuter Bekasi-Jakarta. Area kedatangan dianggap lebih longgar dan dapat dirancang lebih rekreatif karena, memang area kedatangan dari stasiun diasumsikan akan didominasi oleh masyarakat yang baru pulang berkegiatan tidak terlalu memerlukan sirkulasi yang efektif dan langsung. Kecepatan gerak manusia dan jumlah massa yang akan melalui suatu ruang juga mempengaruhi bagaimana ruang sirkulasi terbentuk. Dalam rancangan, sirkulasi utama memiliki jalur yang lebih besar karena harus menampung jumlah manusia yang lebih banyak dengan kecepatan gerak yang relatif cepat karena lebih bersifat fungsional dan berorientasi pada satu tempat tujuan.

Eksplorasi dari area sirkulasi yang mencoba merangkap sebagai area rekreatif ditunjukkan selain dalam durasi dan panjangnya ruang sirkulasi juga dengan penyelesaian ruangruang yang berada disekitar yang lebih banyak ditujukan untuk kegiatan komersial yang sifatnya menghibur ataupun

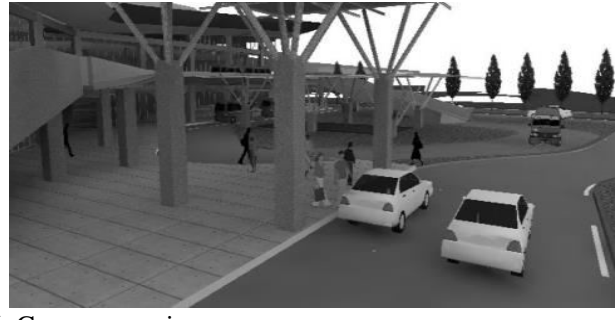

Gambar 16. Gapura penerima.

Sumber Dokumen Pribadi

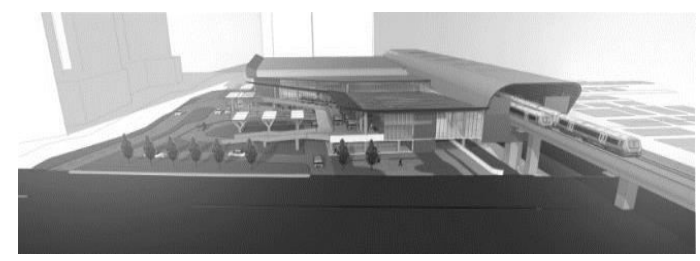

Gambar 17. Area penerima.

yang memang bertujuan komersial. Pengguna seakan digiring untuk harus melalui daerah tersebut, meskipun masih terbukanya peluang-peluang lain dalam pemilihan rute berpindah, misalnya dengan menggunakan lift akan mempercepat sirkulasi. Maka dari itu juga, penempatan lift tidak banyak, hanya untuk mewadahi pengguna yang difable.

Pola sirkulasi pejalan kaki pada rancangan ini linear bercabang, dimana garis linear terbesarnya merupakan alur utama dan memiliki cabang besar menuju area-area yang diutamakan, dan memiliki cabang-cabang kecil ke ruang atau area lain yang sifatnya penunjang, dan turut memberikan alternatif pilihan dalam berkegiatan di dalam bangunan. Dalam rancangan ini titik-titik utamanya adalah area terminal angkot dan juga area stasiun LRT, dimana jalur ini bersifat langsung terutama pada area keberangkatan, berbeda pada area kedatangan yang cenderung lebih fleksibel yang menawarkan lebih banyak cabang.

\section{KESIMPULAN}

Dalam berarsitektur, bagaimana manusia berpindah di dalam suatu ruang, dan bagaimana manusia berinteraksi dengan ruang dimana mereka berada menjadi salah satu perhatian khusus yang tidak dapat dipisahkan pada proses merancang. Sirkulasi, kaitannya dengan perpindahan dari satu titik ke titik lainnya dan tidak terlepas dari keterhubungan satu ruang dengan ruang lainnya, baik secara fisik, atau visual yang memiliki pengaruhnya terhadap pergerakan elemenelemen pengisinya.

Dalam rancangan Terminal Intermoda Bekasi Timur, halhal yang perlu diperhatikan bukan hanya persoalan teknis terkait dimensi dan skala, namun aspek keamanan dan kenyamanan yang dirasakan oleh penggunanya menjadi tantangan lain bersendiri yang harus diselesaikan.

\section{DAFTAR PUSTAKA}

K. W. Todd, Tapak Ruang dan Struktur. Bandung: Intermatra, 1987. 